Article

\title{
How Do Destinations Frame Cultural Heritage? Content Analysis of Portugal's Municipal Websites
}

\author{
Valeriano Piñeiro-Naval *(D) and Paulo Serra \\ LabCom.IFP—Communication, Philosophy and Humanities, Faculty of Arts and Letters, \\ University of Beira Interior, Rua Marquês D’ Ávila e Bolama, 6201-001 Covilhã, Portugal; \\ paulo.serra@labcom.ubi.pt \\ * Correspondence: vale.naval@labcom.ubi.pt; Tel.: +351-275-242-026 (ext. 1510)
}

Received: 6 December 2018; Accepted: 11 February 2019; Published: 13 February 2019 updates

\begin{abstract}
In the current media context, heavily influenced by information and communication technologies, tourism destinations have a need to promote the most outstanding aspects of their cultures to attract the visitors who stimulate their economies. Websites are one of the tools available to carry out this task and they must be designed to communicate the destinations' heritages persuasively to a worldwide audience. Taking these premises into consideration, the objective of this research is to analyze the cultural heritage content on Portugal's municipal websites. The specific goals are to classify the most recurrent heritage elements and detect how they frame identity based on the 'local-global dialectic'. The results show that the heritage discourse is built on the selection of certain aspects-namely, culinary and architectural assets-which are emphasized through the combined use of local and national frames that strengthen the municipalities' particular values but also the fact that they are integrated into a broader and unified whole: Portugal.
\end{abstract}

Keywords: cultural heritage; destinations; identity frame; municipal websites; content analysis; Portugal

\section{Introduction}

The dynamics between culture, heritage and tourism have inspired a very large number of theoretical reflections and empirical studies [1]. The latest trends explore the use and impact of information and communication technologies [2,3] in these cross-cutting areas. Such is the case of social networks [4-7], e-WOM [8], applications for mobile devices [9,10], big data [11,12], virtual and augmented reality $[13,14]$ and video games $[15,16]$.

Studies on these topics with regard to Portugal are also growing in number [17-20]. Nevertheless, and given our need to establish a starting point for future research, this work focuses on a pioneering piece of ICT that has become established in the media landscape: the world wide web (www). According to Internet World Stats [21], this medium had a penetration of 55.1\% of the world's population in 2018 and was most prominent in Europe (85.2\%), where Portugal is located (77.9\%), and North America (95\%). On the other hand, and in view of macroeconomic figures for the tourist industry, Portugal is increasingly important in the sector. In fact, the Bank of Portugal indicates that tourism revenue in the country amounted to $€ 12.68$ billion in 2016 [22], which represents $9.2 \%$ of Portugal's GDP and national employment [23].

Taking into account these preliminary considerations, this research examines the cultural heritage content included on the official websites of Portugal's municipalities, which are mechanisms for promoting tourism and disseminating identity. Therefore, our study object is one of the most relevant elements for a website's success: the information it contains [24]. To be more precise, the specific 
objectives are to identify the most recurrent cultural and natural heritage assets and the framing of identity in these elements based on the local-global dialectic.

The organization of the paper is as follows: we first delve into theoretical synergies between the domains of culture, heritage and tourism, and then consider online communication as one of the core elements of the identity discourse related to these fields. Next, the method used in the research is presented, that is, the quantitative content analysis of the country's 308 websites. The results, which reflect both univariable and multivariable descriptive data, are presented and this is followed by a qualitative discussion. Finally, the conclusions highlight some key ideas derived from the research, as well as theoretical and methodological implications, limitations and future research lines.

\section{Literature Review}

This chapter provides a brief overview of related theoretical work and the state of the art in these fields.

\subsection{Culture, Heritage and Tourism: A Sustainable Synergy?}

The areas of culture, heritage and tourism are related so closely that it is sometimes difficult to define them independently, given that their individual paradigmatic definitions usually refer to one other.

Culture can be defined as "a set of ideas—values, attitudes, and beliefs-practices—of cultural production—and artifacts—cultural products, texts" [25] (p. 369). These elements are not the exclusive property of an individual, since they are part of a "collective programming of the mind that distinguishes the members of one group or category of people from others" [26] (p. 6). This idea is directly linked to the notion of 'social identity' [27,28]: the part of an individual's concept of self that derives from the knowledge of the social group or groups to which that individual belongs, together with the emotional and evaluative meanings associated with this membership. So, what function does culture play in establishing identities? According to Castells [29], it has an essential role since "identity is the process whereby people draw on a cultural attribute to build meaning in their lives" (p. 62).

Heritage, for its part, is the cultural and natural legacy we receive from previous generations, and "it is widely viewed as a precious and irreplaceable resource, essential to personal and collective identity and necessary for self-respect" [30] (p. 81). Lowenthal's observation indicates that, like culture, heritage has a special impact on the formation of community identity: "it is the way in which the past is used now that underscores our values as a society and sets the tone for future development and growth" [31] (p. 304). Therefore, and although heritage refers to the past, the implications of its present conservation are oriented towards its future use because we must not forget that, in addition to its important cultural and identity connotations, "heritage is an industry itself involving labor capital, and revenue on a tremendous scale-whether within management, outreach, or the world's tourist industry" [32] (pp. 117-118).

Within this line that extols the mercantilist aspect of heritage, many voices claim that heritage can contribute decisively to the development of regions or countries and especially the cities and towns that comprise them. This reasoning would apply to tangible heritage assets, both cultural and natural, and also intangible ones: "skills and practices which found the individual's and the community's identity and dignity, and whose reproduction entails the transmission and enrichment of tacit, informal capabilities" [33] (p. 263).

The tourism industry—one of the most powerful in the world due to its significant role over the last two decades [34] - gradually relies on heritage and culture as assets on which to sustain its diversified offer and the branding of destinations [35]. As the Organization for Economic Co-operation and Development has pointed out, this has led to a trend of growing impact on territories' economies: "it is clear that tourism and culture have become increasingly closely linked as their role in regional attractiveness and competitiveness has become clearer" [36] (p. 35). 
Therefore, cultural tourism is "the movement of people for strictly cultural reasons" [37] (p. 46). Richards [38] affirms that "cultural sights, attractions and events provide an important motivation for travel, and travel in itself generates culture. But it has only been in recent decades that the link between culture and tourism has been more explicitly identified as a specific form of consumption: cultural tourism" (p. 12). For Cohen [39], this is a type of tourism that aims to distinguish people who practice it and is characteristic of people who possess a relatively high level of cultural capital, sophistication and reflexivity in relation to the heritage assets they observe and interact with. Today's tourists are demanding and want to get the most out of their 'experiences' - a concept to which we will return in the conclusion.

In short, and to complete the conceptual triangulation formed by 'culture, heritage and tourism', we must not forget that heritage conservation and exploitation meets several objectives, not only related to tourism [40]. People who reside in territories that possess this type of heritage recognize themselves in it through a narrative that is consistent with identity group consciousness and are able to make use of heritage not only for the purposes of economic exploitation, but also for their own cultural enrichment. This process must be monitored by those responsible for local tourism governance [41], among others, to produce sustainable dynamics between these three closely related fields and ensure the locals' quality of life and to reinforce the municipalities' attractiveness as destinations to visit.

\subsection{Online Communication: A Tool for Glocal Discourse}

This study does not aim to delve into concepts with deep theoretical importance and long trajectories such as cultural globalization, glocalization and hybridization. However, it is useful to mention them to outline the current postmodern identity context, which is clearly mediated by digital and ubiquitous communication.

According to Bauman [42], "globalization does not mean cultural unification; the mass production of cultural material does not lead to the emergence of anything like global culture" (p. 43). As a result, while it may not be possible to talk about an alienating cultural pattern, it may be more appropriate to discuss a mixture, an interaction between global cultural elements and diametrically-opposed local ones. In other words, "the interpenetration of the global and the local resulting in unique outcomes in different geographic areas" [43] (p. 255). To illustrate the functioning of the so-called glocalization phenomenon, we can draw an analogy with the financial and economic universe and equate it to the phenomenon of micro-marketing: "the tailoring and advertising of goods and services on a global or near-global basis to increasingly differentiated local and particular markets" [44] (p. 28).

Related to the concept of glocalization, 'hybridization' is defined as a process by which "external flows interact with internal flows producing a unique cultural hybrid that combines their elements" [43] (p. 255). This trend puts the emphasis on biodiversity resulting from the mixture of the global and the local—an idea that appears neutral and even positive—as opposed to uniformity, which is often associated with the adverse effects of globalization.

Focusing our attention on the media landscape, and in light of the 'infoxication' to which users are exposed, tourist destinations - countries, regions and, as in this case, municipal bodies-face an urgent need to highlight certain aspects of their cultural heritage and natural environments to differentiate themselves from their competition. These creative resources, "produced by people according to their contemporary concerns and experiences" [45] (p. 320), are used to produce symbolic identities, which will serve as the central ideas of tourism marketing strategies [46]. Similarly, these cultural attributes are configured into a kind of narrative that some authors have called 'Authorized Heritage Discourse' $[47,48]$, which is composed of the repertoire of the most noticeable factors at aesthetic and identity levels. This discourse, therefore, gives the bodies that manage heritage the power to define what is worth highlighting from the past and to trace the main lines in the construction of group identity, an "authoritative representation of 'ourselves' or 'our' landscape, traditions, and way of life" [49] (p. 13). 
The logic behind the Authorized Heritage Discourse can be equated to the mechanisms by which 'framing theory' operates [50,51]: the selection of certain aspects of reality to be emphasized in the communicative text, with the consequent exclusion of others. Therefore, and bearing in mind that "the use of Internet to promote regional culture and tourism is becoming indispensable as a promotional tool" [36] (p. 67), towns and cities use their websites to project a cultural and tourist image as attractively and persuasively as possible [52]. The multimedia language of the www enables digital tourists to enjoy a hypertextual and multi-sensory experience while looking at the most outstanding features of the territory [53].

Based on the previous observations, it seems clear that "for tourism, the global and the local form a dyad acting as a dialectical process" [54] (p. 302) and that, in the field of cultural tourism, glocalization "involves tailoring local—and localized-products-representations of heritage and culture-to changing global audiences-international tourists coming from various parts of the world and with different preferences" [55] (p. 631).

After pointing out the dynamics surrounding the fields of culture, heritage and tourism and identifying online communication as an agent of relevance in the transmission of identity values associated with these domains, the following section describes the materials and method used in the study.

\section{Materials and Method}

The method used in this study is content analysis, which "may be briefly defined as the systematic, objective, quantitative analysis of message characteristics" [56] (p. 1). According to Krippendorff [57], "content analysis is a research technique for making replicable and valid inferences from texts-or other meaningful matter-to the contexts of their use" (p. 18). The steps necessary for its application to liquid web environments [58] involve: (1) formulating research questions and hypotheses, (2) selecting a sample, (3) designing a codebook and using it when coding the units of analysis, (4) validating the reliability of the process and, finally, (5) interpreting the results [59-61]. Therefore, and based on the methodological protocol and the findings of our own previous studies in the Spanish $[62,63]$ and Portuguese [64] digital spheres, we are able to pose some research questions (RQ):

- $\mathrm{RQ}_{1}$ : What heritage assets stand out in Portugal's municipal websites at the informative level?

- $\mathrm{RQ}_{2}$ : Are there any differences between the tangible and intangible dimensions of heritage?

- $\mathrm{RQ}_{3}$ : What identity frame is associated with the assets?

- $\mathrm{RQ}_{4}$ : Are there any differences between the tangible and intangible dimensions in terms of their identity frames?

- $\mathrm{RQ}_{5}$ : From the geographical point of view, are there any differences between regions?

In relation to the hypotheses, there is empirical evidence in the Iberian context that there are two fundamental factors that correlate significantly with the state of the local web in terms of culture and tourism: the size of the municipalities' populations and their macro-economic development $[63,64]$. So, it is also important to check the following statements:

- $\mathrm{H}_{1}$ : There is a positive correlation between municipality population size and the amount of heritage information.

- $\mathrm{H}_{2}$ : There is a positive correlation between municipal economic factors and the amount of heritage information.

For the purposes of contrast, the latter hypothesis is divided into the following three second-order hypotheses:

- $\mathrm{H}_{2 \mathrm{a}}$ : There is a positive correlation between municipal budget and the amount of heritage information.

- $\mathrm{H}_{2 \mathrm{~b}}$ : There is a positive correlation between municipal benefits in the field of tourism and the amount of heritage information. 
- $\mathrm{H}_{2 \mathrm{c}}$ : There is a positive correlation between municipal expenditure on cultural activities and the amount of heritage information.

The data from the study were compared with demographic and economic statistics extracted from official government sources, which became independent variables. The following section refers to the sample selection process and the design of the codebook.

\subsection{Sample and Codebook}

The sampling strategy tends to be one of the most delicate steps in any study. When it comes to content analysis, which is typically a quantitative method, designing a representative sample is undeniably valuable [65]. However, in this regard, it was not necessary to design a sampling method because we decided to analyze all of the $N=308$ municipal websites that make up the universe of Portuguese municipalities-that is, all city and village councils—which in turn makes the collected data generalizable.

These websites exist to provide faster service delivery, increased communication and a more engaging platform for civic dialogue [66]. Furthermore, these websites also perform a tourist function because they serve to communicate the leisure and entertainment on offer, as well as monuments located there and the shows and events that take place in the town (for example, see Figure 1). The target readers are, therefore, classified into two different groups: citizens and tourists. Following this, we have found that, in the period during which we conducted the empirical study, the languages used for writing the information were distributed as follows: Portuguese $(100 \%)$, English $(40.3 \%)$, Spanish (30.8\%), French (23.4\%), German (19.5\%) and others (18.8\%). So, we can see that both national and international markets are considered in terms of tourism.

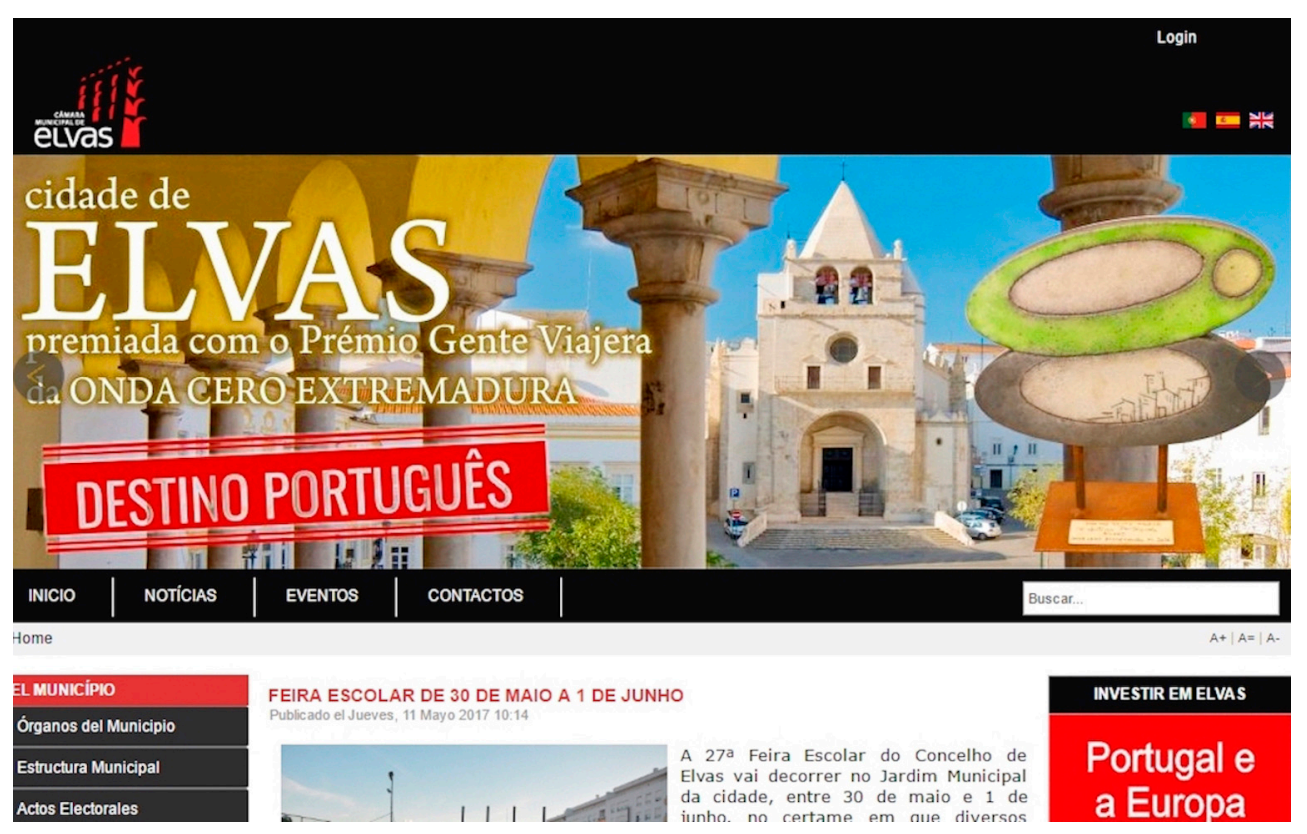

Figure 1. Example of a unit of analysis: screenshot of Elvas' homepage (http:/ / www.cm-elvas.pt/) during the coding process.

The tool of analysis; i.e., the codebook, is composed of 58 variables, of which 30 are dichotomous nominal—or dummy—and 28 are ordinal (see Appendix A). These variables are grouped as follows:

- Tangible cultural heritage assets-12-and their respective identity frames-12;

- Intangible cultural heritage assets—9-and their respective identity frames-9;

- Natural heritage assets-7-and their respective identity frames-7; and 
- Location of heritage information on the official municipal website $(0=$ not located; $1=$ located $)$ or the thematic website on culture, heritage and tourism linked to the main website $(0=$ not located; $1=$ located), which for the purposes of the sample would result in a single unit of analysis in combination with the previous variable.

As mentioned, all items related to heritage assets are dummy variables $(0=$ no information available; 1 = information is available). Regarding identity frames, Carter and Bramley [67] claim that "the significance of natural and cultural resources depends on the number and groups of people who value the area and its resources" (p. 183). Based on this logic, the authors have established six categories):

- Personal and/or familial—of importance to the individual and/or the members of a family.

- Local—of importance to people of one village or local community.

- Regional —of importance to people of more than one village or local community group.

- Provincial—of importance to people extending beyond one city or town.

- National—of importance to people of more than one province.

- International—of importance to people of more than one nation [67] (p. 183).

With regard to the ordinal variables of our analysis, we decided to combine the personal and local categories, as well as the regional and provincial categories, thus establishing the following hierarchy: $0=$ no frame, $1=$ local frame, $2=$ regional frame, 3 = national frame, $4=$ international frame, and $9=$ no information on the asset in question. For Mydland and Grahn [68], "these graduations often correspond to ascribed status, value assessments, formal recognition, and the use of state legislation for preservation" (p. 567). Therefore, after identifying the existence of the heritage asset in question, its framing was evaluated according to:

- Official classification of assets: world heritage site, national historic site, national monument, monument of public interest, monument of municipal interest, etc.

- Nomenclature of assets. Examples are the conservation of unique heritage sites: 'Southwest writing', whose framing is regional; and the 'National fair of green wine, gastronomy and crafts' of Castelo de Paiva, the framing of which is national.

- Identification of keywords in the content of the information. For instance, the 'Cod Festival' of Ílhavo, where 'local history and traditions are aligned', the framing of which is local; and Ponte de Lima, 'Portugal's oldest village', the framing of which is national.

Finally, when two assets had the same label, the one with the widest framing was recorded because the purpose of the study is to detect the elements the municipalities believe to have the greatest reach.

\subsection{Coding, Reliability and Created Indexes}

The $N=308$ websites were analyzed by a team of two coders, trained in advance for this purpose, between 16 March and 8 June 2017. To calculate the intercoder reliability, a random subsample composed of $\sim 12 \%$ of the cases ( $n=37$ websites) was analyzed by both members of the team. This vital part of the protocol was coordinated so that each website would be simultaneously examined by the coders to mitigate the volatility of the contents [69], which is an inherent trait of the Internet that can affect the objectivity of the study if left out of control. The statistical parameter used for reliability was Krippendorff's alpha, a robust statistical test that best fits different scales of measurement as well as a varying number of encoders [70]. The average reliability of the 58 variables of the codebook (see Appendix A) was satisfactory: $M\left(\alpha_{K}\right)=0.75$.

Furthermore, before presenting the results, it is necessary to address the indexes created based on the recoding and computing-using SPSS, version 24-of some variables from the codebook. Thus, we designed 6 different indexes: 3 related to heritage information and 3 to identity frames (see Appendix B). 
The average reliability of the indicators is $M\left(\alpha_{C}\right)=0.70$, which is an acceptable value according to the scales established for descriptive and exploratory studies [71,72]. The procedure for establishing the indicators related to heritage information was simple: the different variables, ranging from ' $0-1$ ' were added and then the result was divided by the same number of variables so that the rates were governed by this theoretical range. The identity frame indicators required the recoding of values prior to computing. The recoding consisted of taking the initial ordinal labels $(0=$ no frame, $1=$ local, $2=$ regional, 3 = national, $4=$ international) and making number 9 (no information on the asset in question) a missing value. The indexes on identity frames were adjusted to a theoretical range of ' $0-4$ ', so that the higher the value, the broader the frame.

\section{Results}

First of all, Table 1 shows the percentage of municipal websites that contain heritage-related information $\left(\mathrm{RQ}_{1}\right)$ and the frame assigned to those elements $\left(\mathrm{RQ}_{3}\right)$ :

Table 1. Percentages of websites with information related to heritage assets and their framing.

\begin{tabular}{|c|c|c|c|c|c|c|}
\hline \multirow{2}{*}{ Heritage Assets } & \multicolumn{5}{|c|}{ Framing } & \multirow{2}{*}{ Total } \\
\hline & No Frame & Local & Regional & National & Global & \\
\hline \multicolumn{7}{|c|}{ Tangible Cultural Heritage } \\
\hline - Religious buildings & 38.3 & 19.5 & 5.2 & 21.1 & 3.2 & 87.3 \\
\hline - Museums and culture houses & 33.1 & 27.3 & 12.3 & 9.7 & 3.9 & 86.3 \\
\hline - Civil and military buildings & 35.7 & 17.5 & 5.2 & 23.4 & 3.6 & 85.4 \\
\hline - Libraries and archives & 30.2 & 38.3 & 0.6 & 11.4 & 0.6 & 81.1 \\
\hline - Archaeological remains & 26.6 & 8.4 & 4.5 & 10.1 & 3.6 & 53.2 \\
\hline - Statues and sculptures & 29.5 & 11.4 & 1.6 & 6.5 & 1 & 50 \\
\hline - Parks and gardens & 35.1 & 6.5 & 0.3 & 1 & 1.6 & 44.5 \\
\hline - Theatres and amphitheatres & 24.4 & 11.7 & 2.3 & 2.6 & 0.6 & 41.6 \\
\hline - Urban complexes & 15.3 & 4.2 & 2.6 & 7.1 & 2.9 & 32.1 \\
\hline - Squares and markets & 19.2 & 2.3 & - & 1 & - & 22.5 \\
\hline - Bullrings & 2.9 & 1.6 & - & 1 & - & 5.5 \\
\hline - Cathedrals and basilicas & 1.3 & 0.3 & - & 3.2 & 0.6 & 5.4 \\
\hline \multicolumn{7}{|c|}{ Intangible Cultural Heritage } \\
\hline - Gastronomy & 22.7 & 24.4 & 31.5 & 8.4 & 4.5 & 91.5 \\
\hline - Religious events & 49.7 & 6.5 & 1.6 & 1.3 & 7.8 & 66.9 \\
\hline - Festive events & 47.4 & 11 & 2.6 & 3.2 & 1.9 & 66.1 \\
\hline - Traditional crafts & 26 & 20.1 & 6.2 & 2.9 & 2.9 & 58.1 \\
\hline - Performing arts & 14 & 6.2 & 4.5 & 3.6 & 9.4 & 37.7 \\
\hline - Important public figures & 5.8 & 2.6 & 0.6 & 12.3 & 2.9 & 24.2 \\
\hline - Oral traditions & 5.8 & 7.5 & 2.3 & 2.6 & 1.6 & 19.8 \\
\hline - Popular customs & 5.2 & 8.4 & 1.3 & 0.3 & 1.9 & 17.1 \\
\hline - Bullfighting & 2.9 & 2.3 & 0.3 & 1.3 & 0.3 & 7.1 \\
\hline \multicolumn{7}{|c|}{ Natural Heritage } \\
\hline - Rivers and fluvial environments & 35.1 & 5.2 & 5.5 & 4.2 & 6.5 & 56.5 \\
\hline - Landscapes and roads & 30.5 & 5.2 & 4.2 & 2.9 & 1.9 & 44.7 \\
\hline - Mountains & 26 & 2.6 & 3.6 & 4.2 & 1.6 & 38 \\
\hline - Flora and fauna & 16.2 & 6.8 & 3.9 & 5.5 & 2.3 & 34.7 \\
\hline - Nature reserves & 6.8 & 0.6 & 3.6 & 11.7 & 4.9 & 27.6 \\
\hline - Coastal formations & 13.3 & 1.6 & 1.9 & 3.2 & 2.3 & 22.3 \\
\hline - Caverns & 4.2 & 0.6 & 0.6 & 1.6 & 0.3 & 7.3 \\
\hline
\end{tabular}

Source: Drawn up by the authors.

The most common tangible heritage assets are religious buildings-national frame, museums and culture houses-local frame, and civil or military buildings-national frame. From an intangible point of view, gastronomy - regional framing — is, without a doubt, the most promoted element. Finally, rivers and fluvial environments_-global framing — are the most frequently-advertised natural asset.

As well as the percentages in Table 1, we also worked with aggregate indicators. In this sense, if we compare the tangible and intangible dimensions of heritage $\left(R Q_{2}\right)$, we can assert that there are significant differences $[t(307)=4.99, p<0.001, d=0.41]$ between the Tangible Cultural Heritage Information Index (TCHI2) and the Intangible Cultural Heritage Information Index (ICHI2), although 
these differences are 'small', looking at the effect size [73]. With regards to the frame indexes $\left(\mathrm{RQ}_{4}\right)$, there also are significant differences [ $t(299)=-2.51, p=0.013, d=-0.19]$ between the Tangible Cultural Heritage Frame Index (TCHFI) and the Intangible Cultural Heritage Frame Index (ICHFI). Figure 2 shows the means of all of these aggregate indicators:

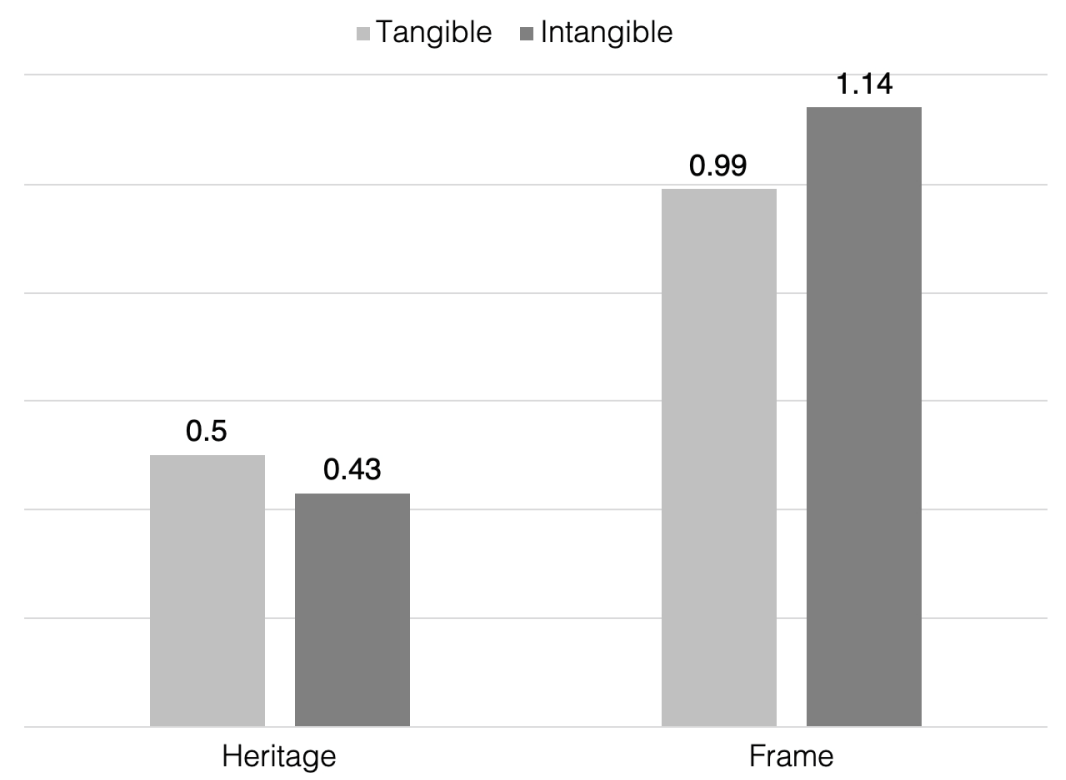

Figure 2. Means of tangible and intangible indexes related to heritage and frame.

According to the numbers shown in Figure 2, the information related to tangible heritage $\left(M_{T C H I 2}=0.50, S D=0.16\right)$ is greater than the information related to intangible heritage $\left(M_{\text {ICHI2 }}=0.43\right.$, $S D=0.18)$. On the other hand, the framing of information on tangible heritage assets $\left(M_{T C H F I}=0.99\right.$, $S D=0.70)$ is smaller than the framing of information on intangible assets $\left(M_{\text {ICHFI }}=1.14, S D=0.86\right)$.

The overall Cultural Heritage Information Index (CHI2) showed the following descriptive values: $M_{C H I 2}=0.47(S D=0.14)$, and a range between ' 0.05 ' and ' 0.86 '. In the case of the Cultural Heritage Frame Index $(\mathrm{CHFI})$, we obtained the following results: $M_{C H F I}=1.02(S D=0.59)$, and a range of ' 0 ' to ' 3 '. The correlation between them is significant $[r(306)=0.17, p<0.01]$, which means that if information about heritage increases, the frame of that information is wider. See other correlations between both indicators and some macro-statistical data below $\left(\mathrm{H}_{1}\right.$ and $\left.\mathrm{H}_{2}\right)$ :

According to Table 2, all correlations are statically significant except for those related to the benefits derived from tourism, which are tendential. Therefore, it has been corroborated that the amount of heritage information and how it is framed depends on the number of inhabitants of the places, the municipal budget, and the money spent by local governments on cultural activities.

Table 2. Correlations between macro-statistical variables and indicators (Pearson's $r$ ).

\begin{tabular}{llccc}
\hline \multicolumn{1}{c}{ Variables (Hypotheses) } & \multicolumn{1}{c}{ Sources } & CHI2 & CHFI & N \\
\hline Number of residents $\left(\mathrm{H}_{1}\right)$ & http://www.ine.pt/ & $0.13^{*}$ & $0.19^{* *}$ & 306 \\
Budget $\left(\mathrm{H}_{2 \mathrm{a}}\right)$ & http://www.portalautarquico.pt/ & $0.28^{* * *}$ & $0.37^{* * *}$ & 306 \\
Benefits derived from tourism $\left(\mathrm{H}_{2 \mathrm{~b}}\right)$ & http://www.pordata.pt/ & $0.13^{+}$ & $0.14^{+}$ & 167 \\
Expenditure on cultural activities $\left(\mathrm{H}_{2 \mathrm{c}}\right)$ & http://www.ine.pt/ & $0.18^{* *}$ & $0.24^{* * *}$ & 306 \\
\hline
\end{tabular}

$$
+p \leq 0.10,{ }^{*} p \leq 0.05,{ }^{* *} p \leq 0.01,{ }^{* * *} p \leq 0.001 \text {. Source: Drawn up by the authors. }
$$

Below, we make several comparisons between geographical areas and regions $\left(\mathrm{RQ}_{5}\right)$. We start with a figure (Figure 3) that presents the mean values of the CHI2 and CHFI depending on geographical areas: coastal, inland and islands-Madeira and Azores: 


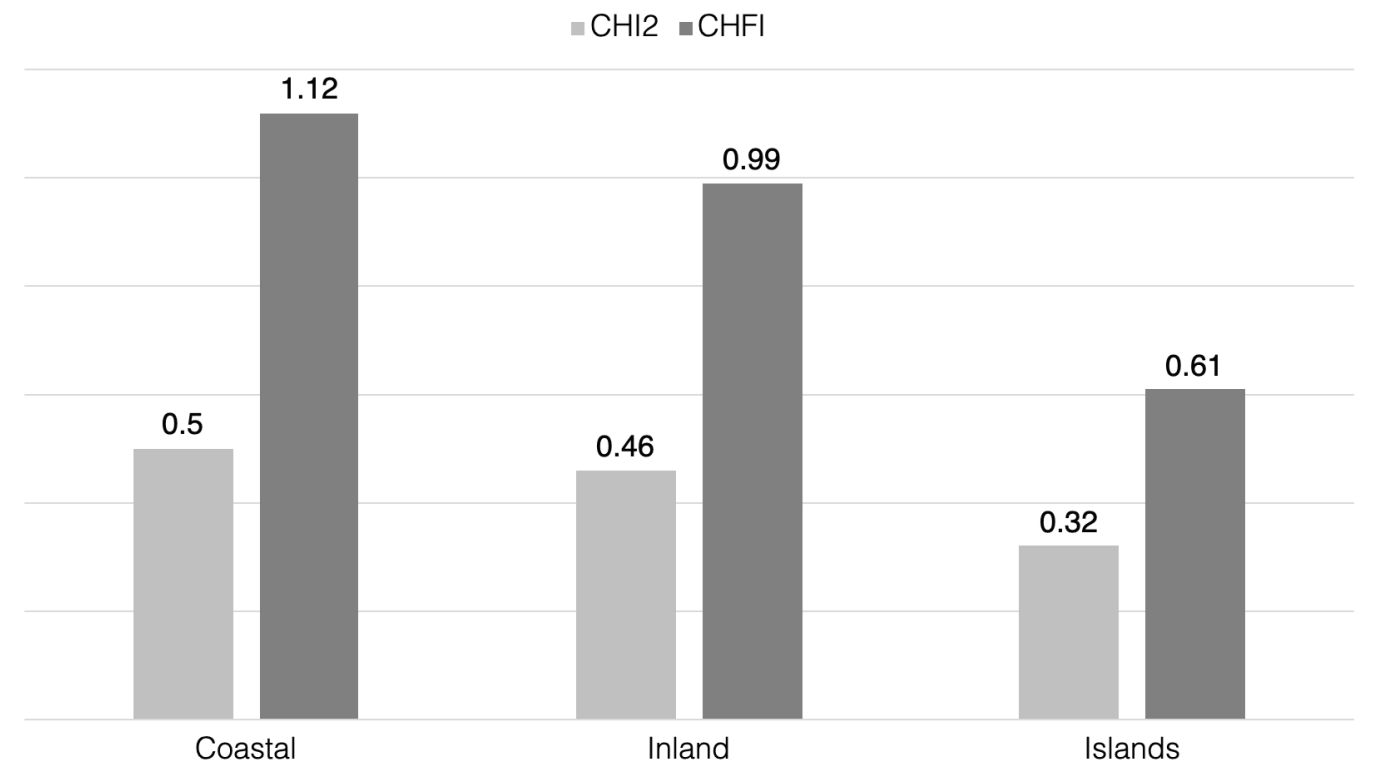

Figure 3. Means of CHI2 and CHFI with regard to geographical areas (analysis of variance, ANOVA).

As we can see in Figure 3, the analysis of variance (ANOVA) shows significant differences in relation to the CHI2 according to geographical area $\left[F_{\text {CHI2 }} x\right.$ Areas $\left.(2,305)=25.21, p<0.001, \eta^{2}=0.142\right]$. According to Scheffe's test for post hoc analysis, the most significant differences are found between coastal municipalities and island municipalities $(p<0.001)$. However, we also found differences between coastal and inland municipalities $[t(276)=2.30, p=0.022, d=0.33]$. The same situation occurs with the CHFI, since the differences between areas are also significant $\left[F_{\text {CHFI } x \text { Areas }}(2,305)=10.14\right.$, $\left.p<0.001, \eta^{2}=0.062\right]$. The biggest differences were detected between coastal and island municipalities $(p<0.001)$, but they are also significant between coastal and inland municipalities $[t(276)=1.89$, $p=0.06, d=0.23]$.

The next table (Table 3) shows the means of the different regions of the country-NUTS II, Nomenclature of Territorial Units for Statistics—with regard to their CHI2 and CHFI:

Table 3. Means of the Cultural Heritage Information Index (CHI2) and Cultural Heritage Frame Index (CHFI) by NUTS II region (ANOVA).

\begin{tabular}{cccccc}
\hline NUTS II Region & $\boldsymbol{M}_{\text {CHI2 }}$ & SD & $\boldsymbol{M}_{\text {CHFI }}$ & $S \boldsymbol{D}$ & $\boldsymbol{N}$ \\
\hline North & 0.50 & 0.12 & $1.14_{\mathrm{b}}$ & 0.63 & 86 \\
Centre & 0.46 & 0.12 & 1.08 & 0.52 & 100 \\
Alentejo & 0.47 & 0.13 & 0.98 & 0.54 & 58 \\
Algarve & $0.51_{\mathrm{a}}$ & 0.14 & 1.06 & 0.61 & 18 \\
Metropolitan Area of Lisbon & 0.47 & 0.10 & 0.85 & 0.55 & 16 \\
Autonomous Region of Azores & $0.31_{\mathrm{a}}$ & 0.12 & $0.46_{\mathrm{b}}$ & 0.46 & 19 \\
Autonomous Region of Madeira & 0.33 & 0.18 & 0.86 & 0.83 & 11 \\
\hline Total & $\mathbf{0 . 4 7}$ & $\mathbf{0 . 1 4}$ & $\mathbf{1 . 0 2}$ & $\mathbf{0 . 5 9}$ & $\mathbf{3 0 8}$
\end{tabular}

Note: the means accompanied by the subscript letters ' $a$ ' and ' $b$ ' differ significantly $(p<0.001)$. Source: Drawn up by the authors.

The second ANOVA confirms that there are significant differences in relation to the CHI2 according to regions $\left[F_{\text {CHI2 } x \text { NUTS }}(6,301)=8.17, p<0.001, \eta^{2}=0.14\right]$. According to Scheffe's test for post hoc analysis, the most significant differences are found between municipalities in the Lisbon Metropolitan Area and in the Azores [ $t(35)=4.52, p<0.001, d=1.53$ ]. The same situation occurs with the CHFI [F CHFI $x$ NUTS $\left.(6,301)=4.18, p<0.001, \eta^{2}=0.077\right]$, but in this case it is the north which differs from Azores most significantly [ $t(103)=4.41, p<0.001, d=1.45]$. 
Finally, we also measured the existence of a specific culture or heritage website linked to the official municipal one. The results are shown in Table 4:

Table 4. Relationship between the two possible web locations of heritage information: institutional website vs. thematic website (column \%).

\begin{tabular}{lccc}
\hline \multirow{2}{*}{ Thematic Website } & Total \% & \multicolumn{2}{c}{ Institutional Website } \\
\cline { 3 - 4 } & & $\begin{array}{c}\text { Yes, the Information Is } \\
\text { Located Here }\end{array}$ & $\begin{array}{c}\text { No, the Information Is } \\
\text { not Located Here }\end{array}$ \\
\hline Yes, the information is located here & 25.6 & $25.2-$ & $100+$ \\
No, the information is not located here & 74.4 & $74.8+$ & $0-$ \\
\hline $\boldsymbol{N}$ & $\mathbf{3 0 8}$ & $\mathbf{3 0 6}$ & $\mathbf{2}$ \\
\hline \\
\hline
\end{tabular}

Although the percentages regarding the location of heritage information indicate that the institutional municipal websites are the ones that most frequently contain the information $-N=306$, i.e., $99.35 \%$ of the total-, the contingency table that relates both options allows us to affirm that there is a statistically significant association between the inclusion of heritage information on the institutional website and inclusion in a thematic website $\left[\chi^{2}(1, N=308)=5.83, p<0.05, v=0.016\right]$. More specifically, $25.2 \%$ of the municipalities that put heritage information on their official websites also provide such information in a linked thematic website.

\section{Discussion}

A substantive or qualitative interpretation of the quantitative results allows us to state that the main element of Portuguese cultural heritage, widely promoted across the municipal websites, is gastronomy. This fact reflects the country's culinary tradition, deeply rooted in the primary sector-that is, agriculture, livestock and fisheries-which is also capital for its economic fabric. Moreover, gastronomy also serves as a cornerstone for tourism, acting as bait not only for foreign visitors coming to the destination, seduced by its wide range of flavors, but also for locals. As Robinson and Smith [74] state, "our first encounter with another culture is most likely to be with the menu, the waiter and food in a restaurant near a resort" (p. 10).

However, although the main element is intangible, material heritage, as a whole, has the largest presence in the Portuguese network. Thus, religious architecture-churches, chapels, hermitages and monasteries, museum infrastructure-museums, galleries and culture houses, civil engineering heritage - bridges, windmills, lighthouses and farmhouses, and military infrastructure-castles, forts, city walls and towers-are widely promoted by government bodies. This is a noteworthy aspect because architecture- the patterns of designing, building and organizing spaces-also heavily relies on tradition, and preserving this type of heritage is crucial for future generations to maintain their way of life and also the harmonious and genuine aspects of cities.

Finally, rivers and fluvial environments are the most frequently-advertised natural assets. One area in particular stands out: 'Douro Vinhateiro', a spectacular region, recognized by the United Nations Educational, Scientific and Cultural Organization (UNESCO) as a World Heritage Site since 2001, where nature and gastronomy coexist harmoniously, since it is an area dedicated to cultivating vines that are later used to make a multitude of good wines.

With regard to the framing, the most common frame is the local one, followed closely behind by the national frame. These results are consistent with the phenomenon of glocalization, which favors native and genuine over foreign, as well as with Portugal's condition as a country unified in terms of identity. This is also because "on the domestic level, cultural heritage is commonly used to stimulate pride in the (imagined) national history" [75] (p. 130). Therefore, there is a combination of frames that results in a dialectic set halfway between the local and the national. On the other hand, aggregate indicators showed that intangible elements present a broader frame of identity, which means that 
events, rituals and performances are communicated to a more extensive audience compared with material heritage and are considered to be more relevant by municipalities.

Continuing with this overview of the main results, it was found that coastal municipalities and, more specifically, the regions of Lisbon, Porto and Braga put the greatest emphasis on promoting their cultural heritage [64]. This was also to be expected - see Hypotheses 1 and 2 and Table 2-because they are the most populated areas of the country and have the largest financial resources to assign to and preserve their heritage, as well as to undertake strategies to market and promote their cultural and tourist attractions, thereby completing a sustainable cycle that must be perpetuated in the future. These strategies are aimed at the development of what Cohen [39] calls 'distinction tourism', which tends to encourage the transformation and revitalization of the cities of most developed parts of the world, since they seek to become global cultural and tourism hubs through the empowerment of their local heritage.

Following this same trend, it is important to note that the high proportion of municipalities that provide some kind of thematic website on culture and heritage is a clear symptom of the growing importance of these assets for the towns. These multimedia devices are not too expensive if we look at the economic return that they can generate in tourist terms, creating a sustainable synergy between local sources and potential incomes.

\section{Conclusions}

Tourism is increasingly an activity in which goods and services are mobilized to create a form of experience, what Pine and Gilmore [76] call 'memorable experiences' (p. 98). Experiences are important because they are at the basis of our life stories. The perception that we are not only interested in products, but also in the stories that they can tell us and that we can tell about them applies perfectly to tourism. People who visit a place, city, monument or museum do so because they knew stories about them and want to confirm or deepen them by visiting. At the same time, this visit will be the subject of future stories, shared with friends and family, perhaps supported by photographs, selfies, videos and other media [77].

If this need to create memorable experiences and generate stories is valid for tourism in general, it is even more so for the form of tourism that has come to be called 'cultural tourism' [38]. If we understand the concept of culture in its broad, anthropological sense as the source of "an ever-increasing number of experiences and possibilities" [74] (p. 9), then all tourism is becoming cultural. In a world where cultures tend to be increasingly global and homogeneous, tourists seek to experience "the uniqueness of each and the similarities of all" [74] (p. 9).

In view of the interactive and multimedia logics that digital technologies have imposed in the communicative panorama, we can determine that, in fact, "our 'tours' through these sites provide the tourist with the chance not only to be somewhere other than where we are, but to be someone other than who we are. Our identity is in flux as our virtual or actual travels remove us from one location and place us in another" [49] (p. 13). Based on the content analysis performed on the universe of Portuguese municipal websites, we have concluded that the discourse delivered to both the town's native citizens and e-tourists is based on selecting certain cultural aspects-mainly culinary and architectural heritage assets-which are highlighted at identity level through the combined use of local and national frames which reinforce the particular value of the municipalities separately, but also their character integrated into a broader and more unified whole: Portugal. These heritage assets, therefore, fulfill two tasks: they act as tourist attractions and represent common identity points where social groups see themselves self-represented. In the best of cases, this interplay should happen in a sustainable way. Or, as Richards and Marques [78] say: "The discourse should not be about sustainable or responsible tourism-terms which are often used for greenwashing conventional models of tourism-but rather the ability of culture to absorb and even positively transform tourism" (p. 88). In the next years, the challenge of social groups-like municipalities-will be to assimilate tourism as a new form of experiencing their heritages and to share their culture identities with other social groups. 


\subsection{Theoretical and Practical Implications}

Regarding the theoretical implications of our research, we tried to apply 'Authorized Heritage Discourse' $[47,48]$ and 'Framing Theory' $[50,51]$ to point out the main aspects of heritage that municipalities disseminate though their official websites, and the frames of identity that they use-based on a local-global dialectic. However, and taking the advice of Waterton and Watson [79], we have to be cautious with regard to our findings because theories about heritage are still developing and maturing.

What we do believe is that the generalized 'culturalization' of tourism entails opportunities for each and every one of the destination cultures and communities-although not risk-free. We are referring in particular to the following [77]:

1. If what interests the tourist now is more than experiencing one aspect of a culture-nature, monuments, gastronomy, etc.- - experiencing a culture as a whole, its identity, its way of life, then all cultures end up having the same opportunities to attract visitors, and not only those that have sea, or monuments, or festivals, etc.

2. As a result of globalization, cultures become hybrid and even homogeneous. What is increasingly valued by potential visitors is the difference, uniqueness and authenticity of each culture-as we also see in the growing demand for the distant, the exotic and the archaic. Each culture must therefore strive to maintain this difference, without yielding to the temptation to become increasingly 'touristy' in the worst sense of the term.

3. The Information and Communication Technologies-in our case, websites-that characterize today's digital society, accessible to everyone, more or less easy to use and of global and instant reach [80], allow each culture and community to ensure its public visibility. These technologies should be used in a persuasive way to attract visitors, but they also must represent locals.

The risks we anticipate in relation to these opportunities are as follows:

1. The success of a destination or a culture can lead to the attraction of a mass of visitors such that, in a short time, these visitors become invasive, endangering the traditions and ways of life of the community - as is currently happening in cities like Lisbon or Porto. The question that arises in this case is the sustainability of tourism: how to promote a destination without the risk of contributing to its destruction or degradation?

2. As 'the different' is being incorporated into global tourist flows, it may tend to cancel out genuine difference, increasingly becoming culture created for the tourist.

3. The public visibility of a community or a culture progressively depends on the information and messages of its own visitors, and less favorable opinions can become a serious risk to the tourist destination.

\subsection{Limitations and Future Research}

Like any empirical study, our work entails certain limitations. Although the paper only provides a content analysis, we believe that we followed the protocol to be systematic, objective and quantitative. We achieved good data regarding intercoder reliability and internal consistency of aggregate indicators, but we have to admit that it was a big challenge to examine the universe or population of Portugal's municipal websites. Indeed, the collection of data was manual, done by human coders, so we have to assume that some information has been missed.

On the other hand, the period of data collection was between 16 March and 8 June 2017. Most of the websites will have been changed in the meantime. This is a problem for all research dealing with the Internet: the volatility of information, requiring us to interpret our results carefully.

Finally, and after completing this first, necessary, approach to the Portuguese reality, a future line of work would follow the studies mentioned in the introduction, which have focused on social networks or mobile applications. More particularly, our next steps will be to survey the website 
managers to learn more about their routines in relation to cultural and tourist information and to conduct an experiment with users to contrast what kinds of tourist narratives on the web (cultural, massive, natural, commercial, integral, etc.) encourage them to visit the destination the most-this strategy will allow us to cover the classic and basic process of communication: source, message and receiver. This can create a better understanding of this complex, dynamic and liquid reality in order to shed more light on an area that still remains in a certain amount of darkness.

Author Contributions: Conceptualization, V.P.N. and P.S.; Method and data analysis, V.P.N.; Writing, V.P.N.; Review and editing: V.P.N. and P.S. All authors approved the final version.

Funding: This research was funded by Portugal's Foundation for Science and Technology, grant number "SFRH/BPD/122402/2016", and by the R\&D Unit LabCom.IFP-Communication, Philosophy and Humanities (Reference: UID/CCI/00661/2013).

Acknowledgments: Assistance provided by Rafael Mangana, PhD candidate at University of Beira Interior, during the data collection is greatly appreciated.

Conflicts of Interest: The authors declare no conflicts of interest.

\section{Appendix A}

Intercoder reliability (Krippendorff's alpha) of variables:

\begin{tabular}{|c|c|c|c|}
\hline $\begin{array}{c}\text { Heritage Elements } \\
\text { (Dichotomous Nominal Variables) }\end{array}$ & $\alpha_{\mathrm{k}}$ & $\begin{array}{c}\text { Frames } \\
\text { (Ordinal Variables) }\end{array}$ & $\alpha_{k}$ \\
\hline 1. Religious buildings & 0.89 & 2. Religious buildings frame & 0.89 \\
\hline Museums and culture houses & 0.64 & 4. Museums and culture houses frame & 0.67 \\
\hline 5. Civil and military buildings & 0.75 & 6. Civil and military buildings frame & 0.66 \\
\hline 7. Libraries and archives & 0.80 & 8. Libraries and archives frame & 0.48 \\
\hline 9. Archaeological remains & 0.88 & 10. Archaeological remains frame & 0.80 \\
\hline 11. Statues and sculptures & 0.84 & 12. Statues and sculptures frame & 0.83 \\
\hline 13. Parks and gardens & 0.71 & 14. Parks and gardens frame & 0.74 \\
\hline 15. Theatres and amphitheatres & 0.63 & 16. Theatres and amphitheatres frame & 0.58 \\
\hline 17. Urban complexes & 0.81 & 18. Urban complexes frame & 0.75 \\
\hline 19. Squares and markets & 0.73 & 20. Squares and markets frame & 0.74 \\
\hline 21. Bullrings & 0.66 & 22. Bullrings frame & 0.68 \\
\hline 23. Cathedrals and basilicas & 1 & 24. Cathedrals and basilicas frame & 1 \\
\hline 25. Gastronomy & 0.80 & 26. Gastronomy frame & 0.54 \\
\hline 27. Religious events & 0.73 & 28. Religious events frame & 0.68 \\
\hline 29. Festive events & 0.78 & 30. Festive events frame & 0.66 \\
\hline 31. Traditional crafts & 0.89 & 32. Traditional crafts frame & 0.90 \\
\hline 33. Performing arts & 0.54 & 34. Performing arts frame & 0.47 \\
\hline Important public figures & 0.65 & 36. Important public figures frame & 0.57 \\
\hline 37. Oral traditions & 0.80 & 38. Oral traditions frame & 0.83 \\
\hline 39. Popular customs & 0.79 & 40. Popular customs frame & 0.78 \\
\hline 41. Bullfighting & 0.84 & 42. Bullfighting frame & 0.82 \\
\hline 43. Rivers \& fluvial environments & 0.68 & 44. Rivers \& fluvial environments frame & 0.60 \\
\hline 45. Landscapes and roads & 0.66 & 46. Landscapes and roads frame & 0.54 \\
\hline Flora and fauna & 0.72 & 48. Flora and fauna frame & 0.68 \\
\hline Mountains & 0.63 & Mountains frame & 0.61 \\
\hline Nature reserves & 0.83 & Nature reserves frame & 0.85 \\
\hline Coastal formations & 1 & 54. Coastal formations frame & 1 \\
\hline Caverns & 1 & 56. Caverns frame & 1 \\
\hline \multicolumn{4}{|c|}{ Location of Heritage Information (dichotomous nominal variables) } \\
\hline 57. Institutional website & 1 & 58. Thematic website & 0.65 \\
\hline
\end{tabular}

Source: Drawn up by the authors.

\section{Appendix B}

Description of purpose-created indexes: 


\begin{tabular}{|c|c|c|c|c|}
\hline Index & Variables & $M$ & $S D$ & $\alpha_{c}$ \\
\hline $\begin{array}{c}\text { Cultural Heritage } \\
\text { Information Index (CHI2) }\end{array}$ & $\begin{array}{ll}\text { 1. } & \text { Religious buildings } \\
\text { 2. } & \text { Museums and culture houses } \\
\text { 3. } & \text { Civil and military buildings } \\
\text { 4. Libraries and archives } \\
\text { 5. Archaeological remains } \\
\text { 6. Statues and sculptures } \\
\text { 7. Parks and gardens } \\
\text { 8. Theatres and amphitheatres } \\
\text { 9. Urban complexes } \\
\text { 10. Squares and markets } \\
\text { 11. Bullrings } \\
\text { 12. Cathedrals and basilicas } \\
\text { 13. Gastronomy } \\
\text { 14. Religious events } \\
\text { 15. Festive events } \\
\text { 16. Traditional crafts } \\
\text { 17. Performing arts } \\
\text { 18. Important public figures } \\
\text { 19. Oral traditions } \\
\text { 20. Popular customs } \\
\text { 21. } \text { Bullfighting }\end{array}$ & 0.47 & 0.14 & 0.60 \\
\hline $\begin{array}{l}\text { Tangible Cultural Heritage } \\
\text { Information Index (TCHI2) }\end{array}$ & $\begin{array}{l}\text { 1. Religious buildings } \\
\text { 2. Museums and culture houses } \\
\text { 3. Civil and military buildings } \\
\text { 4. Libraries and archives } \\
\text { 5. Archaeological remains } \\
\text { 6. Statues and sculptures } \\
\text { 7. Parks and gardens } \\
\text { 8. Theatres and amphitheatres } \\
\text { 9. Urban complexes } \\
\text { 10. Squares and markets } \\
\text { 11. Bullrings } \\
\text { 12. Cathedrals and basilicas }\end{array}$ & 0.50 & 0.16 & 0.55 \\
\hline $\begin{array}{l}\text { Intangible Cultural Heritage } \\
\text { Information Index (ICHI2) }\end{array}$ & $\begin{array}{ll}\text { 1. } & \text { Gastronomy } \\
\text { 2. } & \text { Religious events } \\
\text { 3. } & \text { Festive events } \\
\text { 4. } & \text { Traditional crafts } \\
\text { 5. } & \text { Performing arts } \\
\text { 6. } & \text { Important public figures } \\
\text { 7. } & \text { Oral traditions } \\
\text { 8. } & \text { Popular customs } \\
\text { 9. } & \text { Bullfighting }\end{array}$ & 0.43 & 0.18 & 0.52 \\
\hline $\begin{array}{l}\text { Cultural Heritage Frame } \\
\text { Index (CHFI) }\end{array}$ & $\begin{array}{l}\text { 1. Religious buildings frame } \\
\text { 2. Museums and culture houses frame } \\
\text { 3. Civil and military buildings frame } \\
\text { 4. Libraries and archives frame } \\
\text { 5. Archaeological remains frame } \\
\text { 6. Statues and sculptures frame } \\
\text { 7. Parks and gardens frame } \\
\text { 8. Theatres and amphitheatres frame } \\
\text { 9. Urban complexes frame } \\
\text { 10. Squares and markets frame } \\
\text { 11. Bullrings frame } \\
\text { 12. Cathedrals and basilicas frame } \\
\text { 13. Gastronomy frame } \\
\text { 14. Religious events frame } \\
\text { 15. Performing arts frame }\end{array}$ & 1.02 & 0.59 & 0.95 \\
\hline
\end{tabular}




\begin{tabular}{|c|c|c|c|c|}
\hline Index & Variables & $M$ & $S D$ & $\alpha_{c}$ \\
\hline $\begin{array}{l}\text { Tangible Cultural Heritage } \\
\text { Frame Index (TCHFI) }\end{array}$ & $\begin{array}{l}\text { 1. Religious buildings frame } \\
\text { 2. Museums and culture houses frame } \\
\text { 3. Civil and military buildings frame } \\
\text { 4. Libraries and archives frame } \\
\text { 5. Archaeological remains frame } \\
\text { 6. Statues and sculptures frame } \\
\text { 7. Parks and gardens frame } \\
\text { 8. Theatres and amphitheatres frame } \\
\text { 9. Urban complexes frame } \\
\text { 10. Squares and markets frame } \\
\text { 11. Bullrings frame }\end{array}$ & 0.99 & 0.70 & 0.96 \\
\hline $\begin{array}{l}\text { Intangible Cultural Heritage } \\
\text { Frame Index (ICHFI) }\end{array}$ & $\begin{array}{l}\text { 1. Gastronomy frame } \\
\text { 2. Religious events frame } \\
\text { 3. Festive events frame } \\
\text { 4. Traditional crafts frame } \\
\text { 5. Performing arts frame } \\
\text { 6. Important public figures frame } \\
\text { 7. Oral traditions frame } \\
\text { 8. Popular customs frame }\end{array}$ & 1.14 & 0.86 & 0.58 \\
\hline
\end{tabular}

Source: Drawn up by the authors.

\section{References}

1. Standing, C.; Tang-Taye, J.P.; Boyer, M. The Impact of the Internet in Travel and Tourism: A Research Review 2001-2010. J. Travel Tour. Mark. 2014, 31, 82-113. [CrossRef]

2. King, L.; Stark, J.F.; Cooke, P. Experiencing the Digital World: The Cultural Value of Digital Engagement with Heritage. Herit. Soc. 2016, 9, 76-101. [CrossRef]

3. Neidhardt, J.; Werthner, H. IT and tourism: Still a hot topic, but do not forget IT. Inf. Technol. Tour. $2018,20$. [CrossRef]

4. Stepchenkova, S.; Zhan, F. Visual destination images of Peru: Comparative content analysis of DMO and user-generated photography. Tour. Manag. 2013, 36, 590-601. [CrossRef]

5. Fatanti, M.N.; Suyadnya, I.W. Beyond User Gaze: How Instagram Creates Tourism Destination Brand? Procedia Soc. Behav. Sci. 2015, 211, 1089-1095. [CrossRef]

6. Taylor, J.; Gibson, L.K. Digitisation, digital interaction and social media: Embedded barriers to democratic heritage. Int. J. Herit. Stud. 2017, 23, 408-420. [CrossRef]

7. Farahani, L.M.; Motamed, B.; Ghadirinia, M. Investigating heritage sites through the lens of social media. J. Archit. Urban. 2018, 42, 199-211. [CrossRef]

8. Mehmood, S.; Liang, C.; Gu, D. Heritage Image and Attitudes toward a Heritage Site: Do They Really Mediate the Relationship between User-Generated Content and Travel Intentions toward a Heritage Site? Sustainability 2018, 10, 4403. [CrossRef]

9. Schieder, T.K.; Adukaite, A.; Cantoni, L. Mobile Apps Devoted to UNESCO World Heritage Sites: A Map. In Information and Communication Technologies in Tourism 2014; Xiang, Z., Tussyadiah, I., Eds.; Springer International Publishing: Cham, Switzerland, 2013; pp. 17-29.

10. Dickinson, J.E.; Ghali, K.; Cherrett, T.; Speed, C.; Davies, N.; Norgate, S. Tourism and the smartphone app: Capabilities, emerging practice and scope in the travel domain. Curr. Issues Tour. 2014, 17, 84-101. [CrossRef]

11. Jackson, S. Prediction, explanation and big(ger) data: A middle way to measuring and modelling the perceived success of a volunteer tourism sustainability campaign based on 'nudging'. Curr. Issues Tour. 2016, 19, 643-658. [CrossRef]

12. Xiang, Z.; Fesenmaier, D.R. Tourism on the Verge. Analytics in Smart Tourism Design. Concepts and Methods; Springer: Cham, Switzerland, 2017.

13. Han, D.I.; Tom Dieck, M.C.; Jung, T. User experience model for augmented reality applications in urban heritage tourism. J. Herit. Tour. 2018, 13, 46-61. [CrossRef]

14. Yung, R.; Khoo-Lattimore, C. New realities: A systematic literature review on virtual reality and augmented reality in tourism research. Curr. Issues Tour. 2017, 1-26. [CrossRef] 
15. Mortara, M.; Catalano, C.E.; Bellotti, F.; Fiucci, G.; Houry-Panchetti, M.; Petridis, P. Learning cultural heritage by serious games. J. Cult. Herit. 2014, 15, 318-325. [CrossRef]

16. Xu, F.; Tian, F.; Buhalis, B.; Weber, J.; Zhang, H. Tourists as Mobile Gamers: Gamification for Tourism Marketing. J. Travel Tour. Mark. 2016, 33, 1124-1142. [CrossRef]

17. Lopes, R.; Abrantes, J.L.; Kastenholz, E. Innovation, tourism and social networks. Rev. Tur. Desenvolv. 2014, 21-22, 151-154.

18. Ramos, D.M.; Costa, C. Turismo: Tendências de evolução. PRACS Revista Eletrônica de Humanidades do Curso de Ciências Sociais da UNIFAP 2017, 10, 21-33. [CrossRef]

19. Gholitabar, S.; Alipour, H.; Costa, C. An Empirical Investigation of Architectural Heritage Management Implications for Tourism: The Case of Portugal. Sustainability 2018, 10, 93. [CrossRef]

20. Liberato, P.M.C.; Alén-González, E.; Liberato, D.F.V.A. Digital Technology in a Smart Tourist Destination: The Case of Porto. J. Urban Technol. 2018, 25, 75-97. [CrossRef]

21. Internet World Stats. Available online: https:/ / www.internetworldstats.com (accessed on 7 January 2019).

22. Banco de Portugal. Available online: https://www.bportugal.pt (accessed on 7 January 2019).

23. OECD (Organization for Economic Co-operation and Development). OECD Tourism Trends and Policies 2016. Highlights; OECD Publications: Paris, France, 2016.

24. Park, Y.A.; Gretzel, U. Success factors for destination marketing web sites: A qualitative meta-analysis. J. Travel Res. 2007, 46, 46-63. [CrossRef]

25. Hanitzsch, T. Deconstructing Journalism Culture: Toward a Universal Theory. Commun. Theory 2007, 17, 367-385. [CrossRef]

26. Hofstede, G.; Hofstede, G.J.; Minkov, M. Cultures and Organizations. Software of the Mind. Intercultural Cooperation and Its Importance for Survival, 3rd ed.; McGraw Hill Professional: New York, NY, USA, 2010.

27. Tajfel, H. Human Groups and Social Categories; Cambridge University Press: Cambridge, UK, 1981.

28. Turner, J.C.; Oakes, P.J.; Haslam, S.A.; McGarty, C. Self and collective: Cognition and social context. Personal. Soc. Psychol. Bull. 1994, 20, 454-463. [CrossRef]

29. Castells, M. Globalisation and identity. A comparative perspective. Transfer. J. Contemp. Cult. 2006, 1, 56-67.

30. Lowenthal, D. Natural and Cultural Heritage. Int. J. Herit. Stud. 2005, 11, 81-92. [CrossRef]

31. Shipley, R.; Snyder, M. The role of heritage conservation districts in achieving community economic development goals. Int. J. Herit. Stud. 2013, 19, 304-321. [CrossRef]

32. Biehl, P.F.; Prescott, C. The Future of Heritage in a Globalized World. In Heritage in the Context of Globalization. Europe and the Americas; Biehl, P.F., Prescott, C., Eds.; Springer: New York, NY, USA, 2013; pp. 117-121.

33. Alberti, F.G.; Giusti, J.D. Cultural heritage, tourism and regional competitiveness: The Motor Valley cluster. Cityculture Soc. 2012, 3, 261-273. [CrossRef]

34. Manera, C.; Valle, E. Tourist Intensity in the World, 1995-2015: Two Measurement Proposals. Sustainability 2018, 10, 4546. [CrossRef]

35. Morgan, N.; Pritchard, A.; Pride, R. Destination Brands: Managing Place Reputation, 3rd ed.; Elsevier: Oxford, UK, 2011.

36. OECD (Organization for Economic Co-operation and Development). The Impact of Culture on Tourism; OECD Publications: Paris, France, 2009.

37. Galí-Espelt, N. Identifying cultural tourism: A theoretical methodological proposal. J. Herit. Tour. 2012, 7, 45-58. [CrossRef]

38. Richards, G. Cultural tourism: A review of recent research and trends. J. Hosp. Tour. Manag. 2018, 36, $12-21$. [CrossRef]

39. Cohen, E. Principales tendencias en el turismo contemporáneo. Política Soc. 2005, 42, 11-24.

40. Chang, T.C.; Milne, S.; Fallon, D.; Pohlmann, C. Urban Heritage Tourism. The Global-Local Nexus. Ann. Tour. Res. 1996, 23, 284-305. [CrossRef]

41. Beaumont, N.; Dredge, D. Local tourism governance: A comparison of three network approaches. J. Sustain. Tour. 2010, 18, 7-28. [CrossRef]

42. Bauman, Z. On Glocalization: Or Globalization for some, Localization for some Others. Thesis Elev. 1998, 54, 37-49. [CrossRef]

43. Ritzer, G. Globalization: A Basic Text; Wiley-Blackwell: West Sussex, UK, 2010.

44. Robertson, R. Glocalization: Time-Space and Homogeneity-Heterogeneity. In Global Modernities; Featherstone, M., Lash, S., Robertson, R., Eds.; Sage: London, UK, 1995; pp. 25-44. 
45. Harvey, D.C. Heritage Pasts and Heritage Presents: Temporality, meaning and the scope of heritage studies. Int. J. Herit. Stud. 2001, 7, 319-338. [CrossRef]

46. Richards, G. Creativity and tourism: The state of the art. Ann. Tour. Res. 2011, 38, 1225-1253. [CrossRef]

47. Smith, L. Uses of Heritage; Routledge: New York, NY, USA, 2006.

48. Waterton, E.; Smith, L. The recognition and misrecognition of community heritage. Int. J. Herit. Stud. 2010, 16, 4-15. [CrossRef]

49. Hallett, R.W.; Kaplan-Weinger, J. Official Tourism Websites: A Discourse Analysis Perspective; Channel View Publications: Bristol, UK, 2010.

50. Entman, R.M. Framing: Toward clarification of a fractured paradigm. J. Commun. 1993, 43, 51-58. [CrossRef]

51. Entman, R.M.; Matthes, J.; Pellicano, L. Nature, Sources, and Effects of News Framing. In The Handbook of Journalism Studies; Wahl-Jorgensen, K., Hanitzsch, T., Eds.; Routledge: New York, NY, USA, 2009; pp. 175-190.

52. Lee, W.; Gretzel, U. Designing persuasive destination websites: A mental imagery processing perspective. Tour. Manag. 2012, 33, 1270-1280. [CrossRef]

53. Urry, J.; Larsen, J. The Tourist Gaze 3.0; SAGE Publications: London, UK, 2011.

54. Teo, P.; Li, L.H. Global and local interactions in tourism. Ann. Tour. Res. 2003, 30, 287-306. [CrossRef]

55. Salazar, N.B. Tourism and Glocalization. 'Local' Tour Guiding. Ann. Tour. Res. 2005, 32, 628-646. [CrossRef]

56. Neuendorf, K.A. The Content Analysis Guidebook, 2nd ed.; Sage: Thousand Oaks, CA, USA, 2016.

57. Krippendorff, K. Content Analysis. An Introduction to Its Methodology; Sage: Thousand Oaks, CA, USA, 2004.

58. Kautsky, R.; Widholm, A. Online Methodology: Analysing News Flows of Online Journalism. Westminst. Pap. Commun. Cult. 2008, 5, 81-97. [CrossRef]

59. McMillan, S.J. The microscope and the moving target: The Challenge of applying content analysis to the World Wide Web. J. Mass Commun. Q. 2000, 77, 80-98. [CrossRef]

60. Sjøvaag, H.; Stavelin, E. Web media and the quantitative content analysis: Methodological challenges in measuring online news content. Converg. Int. J. Res. Into New Media Technol. 2012, 18, 215-229. [CrossRef]

61. Weare, C.; Lin, W.Y. Content analysis of the World Wide Web. Opportunities and challenges. Soc. Sci. Comput. Rev. 2000, 18, 272-292. [CrossRef]

62. Piñeiro-Naval, V.; Igartua, J.J. La difusión del Patrimonio a través de Internet. El caso de Castilla y León. Cuadernos de Turismo 2012, 30, 191-217.

63. Piñeiro-Naval, V.; Igartua, J.J.; Rodríguez-de-Dios, I. Identity-related implications of the dissemination of cultural heritage through the Internet: A study based on Framing Theory. Commun. Soc. 2018, 31, 1-21.

64. Piñeiro-Naval, V.; Serra, P.; Mangana, R. Local development and tourism. The socio-economic impact of digital communication in Portugal. Rev. Lat. Comun. Soc. 2017, 72, 1515-1535. [CrossRef]

65. Riffe, D.; Lacy, S.; Fico, F. Analyzing Media Messages. Using Quantitative Content Analysis in Research, 3rd ed.; Routledge: New York, NY, USA, 2014.

66. Wang, S.; Feeney, M.K. Determinants of Information and Communication Technology Adoption in Municipalities. Am. Rev. Public Adm. 2016, 46, 292-313. [CrossRef]

67. Carter, R.W.; Bramley, R. Defining Heritage Values and Significance for Improved Resource Management: An application to Australian tourism. Int. J. Herit. Stud. 2002, 8, 175-199. [CrossRef]

68. Mydland, L.; Grahn, W. Identifying heritage values in local communities. Int. J. Herit. Stud. 2012, 18, 564-587. [CrossRef]

69. Karlsson, M. Charting the liquidity of online news: Moving towards a method for content analysis of online news. Int. Commun. Gaz. 2012, 74, 385-402. [CrossRef]

70. Hayes, A.F.; Krippendorff, K. Answering the call for a standard reliability measure for coding data. Commun. Methods Meas. 2007, 1,77-89. [CrossRef]

71. Hayes, A.F. Statistical Methods for Communication Science; Lawrence Erlbaum Associates: Mahwah, NJ, USA, 2005.

72. Hair, J.F.; Black, W.C.; Babin, B.J.; Anderson, R.E. Multivariate Data Analysis, 7th ed.; Pearson Prentice Hall: Upper Saddle River, NJ, USA, 2010.

73. Cohen, J. Statistical Power Analysis for the Behavioral Sciences, 2nd ed.; Lawrence Earlbaum Associates: Hillsdale, NJ, USA, 1988.

74. Robinson, M.; Smith, M. Politics, power and play: The shifting contexts of cultural tourism. In Cultural Tourism in a Changing World: Politics, Participation and (re) Presentation; Smith, M., Robinson, M., Eds.; Channel View Publications: Clevedon, UK, 2006; pp. 1-17. 
75. Salazar, N.B. The glocalisation of heritage through tourism. Balancing standardisation and differentiation. In Heritage and Globalization; Labadi, S., Long, C., Eds.; Routledge: New York, NY, USA, 2010; pp. 130-146.

76. Pine, B.J.; Gilmore, J.H. The Experience Economy: Work is Theatre E Every Bussiness a Stage; Harvard Business School Press: Boston, MA, USA, 1999.

77. Piñeiro-Naval, V.; Serra, P. (Eds.) Cultura, Património e Turismo na Sociedade Digital: Uma perspetiva ibírica; Editora LabCom.IFP: Covilhã, Portugal, 2018.

78. Richards, G.; Marques, L. Creating Synergies between Cultural Policy and Tourism for Permanent and Temporary Citizens; United Cities and Local Governments: Barcelona, Spain, 2018.

79. Waterton, E.; Watson, S. Framing theory: Towards a critical imagination in heritage studies. Int. J. Herit. Stud. 2013, 19, 546-561. [CrossRef]

80. Qian, J.; Law, R.; Wei, J. Knowledge mapping in travel website studies: A scientometric review. Scand. J. Hosp. Tour. 2018. [CrossRef]

(C) 2019 by the authors. Licensee MDPI, Basel, Switzerland. This article is an open access article distributed under the terms and conditions of the Creative Commons Attribution (CC BY) license (http:// creativecommons.org/licenses/by/4.0/). 